Original Research Paper

\title{
Kemampuan Berpikir Kritis dan Penguasaan Konsep Dasar IPA Peserta Didik
}

\author{
Agus Ramdani $^{1 *}$, A Wahab Jufri' ${ }^{1}$, Jamaludin $^{1}$, Dadi Setiadi ${ }^{1}$ \\ ${ }^{1}$ Program Studi Pendidikan Biologi, Fakultas Keguruan dan Ilmu Pendidikan Universitas Mataram, Indonesia
}

DOI: $10.29303 /$ jppipa.v6i1.388

Citation: Ramdani, A., Jufri, A., Jamaluddin, J., \& Setiadi, D. (2020). Kemampuan Berpikir Kritis dan Penguasaan Konsep Dasar IPA Peserta Didik. Jurnal Penelitian Pendidikan IPA, 6(1). pp. 119-124.

\section{Article history}

Received: November $20^{\text {th }}$

2019

Revised: January $20^{\text {th }} 2020$

Accepted: January $30^{\text {th }} 2020$

\section{*Corresponding Author:}

Agus Ramdani; Program

Studi Pendidikan Biologi,

Fakultas Keguruan dan Ilmu

Pendidikan Universitas

Mataram, Indonesia

Email:

aramdani07@unram.ac.id

\begin{abstract}
Students must be able to think at a high level in order to meet the requirements of the 21 st century, including the ability to think critically. The mastery of student concepts about a material being studied influences the ability to think critically. The thing to remember is that all forms of critical thinking would not be possible without the main component of mastery of concepts. The purpose of this study is to describe the ability of critical thinking and mastery of the basic concepts of science among SMPN students in Central Lombok Regency. This type of research is a quantitative descriptive research with survey methods. Critical thinking tests and mastery of concepts by students using multiple choice instruments. The results showed that the average results: a) The critical thinking skills of nine high school students in Central Lombok were $71.69 \%$ with high criteria. The second critical thinking indicator, which provides further explanation, achieves the highest score in comparison with other indicators. b) Control of the basic concepts of natural sciences students with $76.20 \%$ with high criteria. The first indicator for controlling the concept is remembering who scores the highest score compared to other indicators.
\end{abstract}

Keywords: Critical Thinking Ability; Mastery of Concepts; Descriptive; Science learning.

Abstrak: Kemampuan berpikir tingkat tinggi harus dimiliki oleh peserta didik untuk menghadapi tuntutan abad 21, salah satunya adalah kemampuan berpikir kritis. Penguasaan konsep peserta didik terhadap suatu materi yang dipelajari mempengaruhi kemampuan berpikir kritis. Hal yang perlu diingat adalah segala bentuk berpikir kritis tidak mungkin dapat dilakukan tanpa komponen utama yaitu penguasaan konsep. Tujuan dari penelitian ini untuk mendeskripsikan kemampuan berpikir kritis dan penguasaan konsep dasar IPA peserta didik SMPN di Kabupaten Lombok Tengah. Jenis penelitian ini merupakan penelitian deskriptif kuantitatif dengan menggunakan metode survey. Tes berpikir kritis dan penguasaan konsep peserta didik menggunakan instrumen pilihan ganda. Hasil penelitian menunjukkan bahwa rerata hasil: a) kemampuan berpikir kritis peserta didik sembilan sekolah SMPN di Lombok Tengah sebesar 71,69\% dengan kriteria tinggi. Indikator berpikir kritis kedua yaitu membuat penjelasan lebih lanjut memperoleh skor tertinggi dibandingkan indikator yang lain. b) penguasaan konsep dasar IPA peserta didik sebesar 76,20\% dengan kriteria tinggi. Indikator penguasaan konsep pertama yaitu mengingat yang memperoleh skor lebih tinggi dibandingkan indikator lainnya.

Kata Kunci: Kemampuan Berpikir Kritis; Penguasaan Konsep; Deskriptif; Pembelajaran IPA.

\section{Pendahuluan}

Pembelajaran IPA menuntut peserta didik memiliki kemampuan abad ke-21 (Hadisaputra et al.,
2019). Kemampuan berpikir kritis menjadi salah satu yang harus dilatih pada peserta didik sehingga kemampuan berpikir kritis peserta didik sangat penting dalam menjamin keberhasilan pembelajaran (Alfonso, 
2015; Sulistyowarni et al, 2019) Berpikir kritis merupakan salah satu hal yang sangat penting harus dilatih pada peserta didik agar peserta didik dapat menyelesaikan persoalan-persoalan konsep IPA yang dihadapinya.

Putra (2015) menjelaskan bahwa kemampuan berpikir kritis merupakan suatu kemampuan proses berpikir yang memungkinkan seseorang untuk mengevaluasi atau menyelidiki bukti, asumsi, dan logika yang mendasari gagasan orang lain. Keterampilan berpikir kritis penting dalam proses pembelajaran karena keterampilan ini memberikan kesempatan kepada peserta didik belajar melalui penemuan (Simbolon \& Tapilouw, 2015). Jufri (2013) menyatakan bahwa berpikir kritis merupakan cara berpikir reflektif yang pokok tujuannya pada pola pengambilan keputusan tentang apa yang dilakukan oleh peserta didik.

Hal lain yang perlu diperhatikan guru dalam mengajarkan IPA adalah membangun penguasaan konsep peserta didik terhadap materi yang diajarkan. Penguasaan konsep sangat diperlukan untuk kesuksesan belajar. Sehubungan dengan itu, penguasaan konsep peserta didik diharapkan mampu mengelola kecakapan kognitif sehingga dapat dilakukan perbaikan pada pembelajaran selanjutnya (Lestari et al, 2019; Sulistyowati, 2012; Ihsan et al, 2019).

Pentingnya mengembangkan kemampuan berpikir kritis dan penguasaan konsep, faktanya belum sejalan dengan kondisi pembelajaran IPA pada saat ini. Salah satu masalah yang dihadapi di Indonesia adalah kelemahan proses belajar, peserta didik kurang didorong untuk mengembangkan kemampuan berpikir mereka, dan belajar di kelas hanya diarahkan untuk menghafal informasi tanpa dituntut untuk mengerti apa yang mereka ingat (Amijaya et al, 2018).

Berdasarkan hasil studi lapangan yang telah dilakukan menunjukkan bahwa strategi pembelajaran yang diterapkan oleh pendidik belum memfasilitasi peserta didik untuk melatih kemampuan berpikir kritis, model pembelajaran masih menggunakan model ceramah dan diskusi sehingga peserta didik cenderung bosan dan pasif dalam kegiatan pembelajaran. Kemampuan berpikir kritis dan penguasaan konsep peserta didik cukup rendah dalam pembelajaran IPA. Hal ini dibuktikan dengan rendahnya nilai hasil belajar peserta didik. Hasil belajar mempengaruhi kemampuan berpikir kritis dan penguasaan konsep peserta didik (Zulkarnain et al, 2019; Zaini, 2016).

Kemampuan berpikir kritis peserta didik dalam pembelajaran IPA sangat diperlukan dalam menghubungkan dan memahami konten materi IPA yang bersifat mikroskopis dan abstrak yang membutuhkan analisis, evaluasi dan interpretasi pikiran peserta didik yang baik (Yustiqvar et al, 2019a). Penelitian ini bertujuan untuk mendeskripsikan kemampuan berpikir kritis dan penguasaan konsep dasar IPA peserta didik di SMPN Kabupaten Lombok Tengah.

\section{Metode}

Penelitian ini merupakan penelitian deskriptif menggunakan metode survei menurut Arikunto (2013). Populasi penelitian ini adalah peserta didik kelas VIII di sembilan sekolah menengah pertama di Kabupaten Lombok Tengah. Sampel penelitian ini terdiri dari dua kelas setiap sekolah. Penelitian ini dilakukan selama enam kali pertemuan. Setiap sesi terdiri dari 80 menit pembelajaran.

Teknik yang digunakan dalam penelitian adalah teknik analisis data deskriptif dengan cara mendeskripsikan dan merangkum hasil pengukuran terhadap kemampuan berpikir kritis dan penguasaan konsep dasar peserta didik SMP yang menjadi sampel penelitain ini. Tes kemampuan berpikir kritis dan penguasaan konsep dasar IPA menggunakan tes pilihan ganda.

Tes berpikir kritis yang dikembangkan mengacu pada indikator berpikir kritis yang dikembangkan oleh Ennis (2018) dan Hughes (2014). Tes penguasaan konsep dasar IPA dikembangkan mengacu pada indikator menurut Bloom (1956) Indikator penguasaan konsep terdiri dari $\mathrm{C} 1=$ mengingat, $\mathrm{C} 2=$ memahami, $\mathrm{C} 3=$ mengaplikasi, $\mathrm{C} 4=$ menganalisis, $\mathrm{C} 5=$ mengevaluasi, dan $\mathrm{C} 6=$ mensintesis. Kriteria berpikir kritis peserta didik menurut Karim (2015) disajikan pada Tabel 1, selanjutnya Kriteria penguasaan konsep peserta didik menurut Agip, (2009) disajikan pada Tabel 2.

Tabel 1. Kriteria Berpikir Kritis

\begin{tabular}{cl}
\hline Skala Perolehan Kategori & Kriteria \\
\hline $81,25<x \leq 100$ & Sangat Tinggi \\
$71,50<x \leq 81,25$ & Tinggi \\
$62,50<x \leq 71,50$ & Sedang \\
$43,75<x \leq 62,50$ & Rendah \\
$0<x \leq 43,75$ & Sangat Rendah \\
\hline
\end{tabular}

Tabel 2. Kriteria Penguasaan Konsep

\begin{tabular}{cl}
\hline Skala Perolehan Kategori & \multicolumn{1}{c}{ Kriteria } \\
\hline $86-100 \%$ & Sangat Tinggi \\
$71-85 \%$ & Tinggi \\
$56-70 \%$ & Sedang \\
$41-55 \%$ & Rendah \\
$0<40 \%$ & Sangat Rendah \\
\hline
\end{tabular}

\section{Hasil dan Pembahasan}

\section{Kemampuan Berpikir Kritis}

Data bepikir kritis peserta didik SMPN sekabupaten Lombok Tengah dikumpulkan dengan 
menggunakan instrumen tes berupa pilihan ganda. Berdasarkan hasil analisis yang telah dilakukan, diperoleh nilai berpikir kritis peserta didik secara keseluruhan disajikan pada Tabel 3.

Tabel 3. Data Berpikir Kritis SMPN Kabupaten Lombok Tengah

\begin{tabular}{llll}
\hline No & Sekolah & Nilai $(\%)$ & Kriteria \\
\hline 1 & Sekolah 1 & 68,70 & Sedang \\
2 & Sekolah 2 & 74,08 & Tinggi \\
3 & Sekolah 3 & 72,84 & Tinggi \\
4 & Sekolah 4 & 71,03 & Sedang \\
5 & Sekolah 5 & 70,91 & Sedang \\
6 & Sekolah 6 & 71,67 & Tinggi \\
7 & Sekolah 7 & 72,67 & Tinggi \\
8 & Sekolah 8 & 71,83 & Tinggi \\
9 & Sekolah 9 & 71,51 & Sedang \\
& Rata-rata & 71,69 & Tinggi \\
\hline
\end{tabular}

Tabel 3 menunjukkan bahwa skor rata-rata berpikir kritis peserta didik dari sembilan sekolah di Lombok Tengah memperoleh skor $71,69 \%$ dengan kriteria tinggi. Hasil ini menunjukkan bahwa peserta didik SMPN se-Kabupaten Lombok Tengah memiliki kemampuan berpikir kritis dengan kriteria tinggi. Hal ini sesuai dengan penjelasan Agip, (2009) bahwa kriteria dengan persentase $71 \%-85 \%$ termasuk dalam kriteria tinggi.

Selanjutnya dilakukan analisis per indikator berpikir kritis. Data hasil analisis yang telah dilakukan, diperoleh nilai rata-rata peserta didik perindikator kemampuan berpikir kritis disajikan pada Gambar 1.

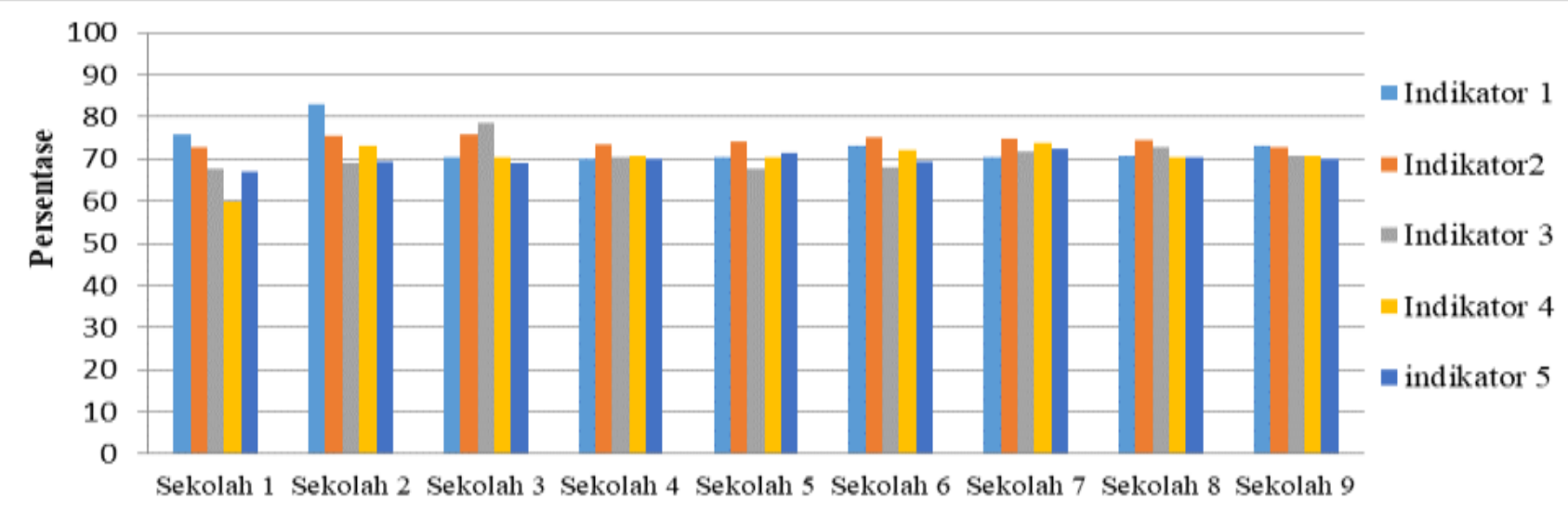

Keterangan:

Gambar 1. Data Berpikir Kritis Peserta Didik SMPN Kabupaten Lombok Tengah Per indicator

Indikator $1=$ Memberikan penjelasan sederhana

Indikator 2 = Membuat penjelasan lebih lanjut

Indikator 3 = Membangun kemampuan dasar

Indikator $4=$ Menganalisis data

Indikator $5=$ Mengidentifikasi asumsi dan memutuskan alternatif untuk solusi

Berdasarkan Gambar 1 menunjukkan bahwa nilai rata-rata kemampuan berpikir kritis peserta didik pada indikator kedua yaitu membuat penjelasan lebih lanjut memperoleh skor tertinggi dibandingkan indikator yang lain. Hal tersebut dikarenakan pada soal yang termasuk indikator kedua ini telah seringkali dipaparkan oleh guru pada saat pembelajaran. Dengan demikian, peserta didik dapat dikatakan telah terbiasa memperoleh informasi yang berulang terkait dengan soal tersebut, sehingga memicu daya ingat peserta didik yang cukup tinggi pada tipe soal ini.

Pernyataan yang mendukung hasil penelitian ini dinyatakan oleh Zakrah et al, (2015) dan Lestari et al, (2019) yang menyatakan bahwa indikator memberikan penjelasan lebih lanjut memperoleh skor lebih tinggi dibandingkan indikator yang lain.

Hasil temuan ini bertolak belakang dengan hasil.
Penelitian dari Qurniati et al. (2015) yang menemukan bahwa indikator memberikan penjelasan lebih lanjut memperoleh nilai yang rendah. Hasil perhitungan $\mathrm{N}$-gain yang menunjukkan kemampuan berpikir kritis peserta didik pada indikator tersebut berada pada rentang nilai yang lebih rendah dari indikator yang lain.

Keterampilan berpikir dapat dilatih melalui pembelajaran yang dirancang menggunakan model konstruktivis. Diantaranya keterampilan berpikir kritis, berpikir kreatif, atau berpikir tingkat tinggi. Singh \& Rahman (2012) menjelaskan program pendidikan lingkungan harus memiliki tujuan yang berkaitan dengan penciptaan kesadaran, akumulasi pengetahuan, sikap positif, keterampilan pemecahan masalah, dan partisipasi masyarakat. 
Pembelajaran IPA untuk meningkatkan kemampuan berpikir peserta didik bisa dilaksanakan dengan menerapkan beberapa cara, diantaranya dengan menggunakan model pembelajaran inkuiri (Puspitasari et al, 2015; Hasanah et al, 2019), model pembelajaran 5 E (Suryani et al, 2017), media pembelajaran dapat meningkatkan kemampuan penguasaan konsep (Yustiqvar et al, 2019b; Ramdani, 2018, Ihsan et al, 2019; Permatasari et al, 2019), penguasaan konsep berpengaruh terhadap kemampuan literasi sains peserta didik, dimana semakin tinggi penguasaan konsep peserta didik, maka semakin tinggi kemampuan berpikir kritis peserta didik.

\section{Penguasaan Konsep Dasar IPA}

Data penguasaan konsep peserta didik SMPN sekabupaten Lombok Tengah dikumpulkan dengan menggunakan instrumen tes berupa pilihan ganda. Berdasarkan hasil analisis yang telah dilakukan, diperoleh nilai penguasaan konsep secara keseluruhan disajikan pada Tabel 4.
Tabel 4. Data Penguasaan Konsep Dasar IPA Peserta Didik SMPN Kabupaten Lombok Tengah

\begin{tabular}{llll}
\hline No & Sekolah & Nilai $(\boldsymbol{\%})$ & Kriteria \\
\hline 1 & Sekolah 1 & 73,56 & Tinggi \\
2 & Sekolah 2 & 78,83 & Tinggi \\
3 & Sekolah 3 & 76,92 & Tinggi \\
4 & Sekolah 4 & 79,83 & Tinggi \\
5 & Sekolah 5 & 80,56 & Tinggi \\
6 & Sekolah 6 & 70,68 & Sedang \\
7 & Sekolah 7 & 69,85 & Sedang \\
8 & Sekolah 8 & 76,73 & Tinggi \\
9 & Sekolah 9 & 78,90 & Tinggi \\
& Rata-rata & 76,20 & Tinggi \\
\hline
\end{tabular}

Tabel 4 menunjukkan bahwa skor rata-rata penguasaan konsep peserta didik dari kesembilan sekolah yang berada di Lombok Tengah memperoleh skor 76,20\% dengan kriteria tinggi. Hasil ini menunjukkan bahwa peserta didik SMPN seKabupaten Lombok Tengah memiliki penguasaan konsep dengan kriteria tinggi. Selanjutnya dilakukan analisis per indikator penguasaan konsep. Data hasil analisis yang telah dilakukan, diperoleh nilai rata-rata peserta didik per indikator penguasaan konsep disajikan pada Gambar 2.

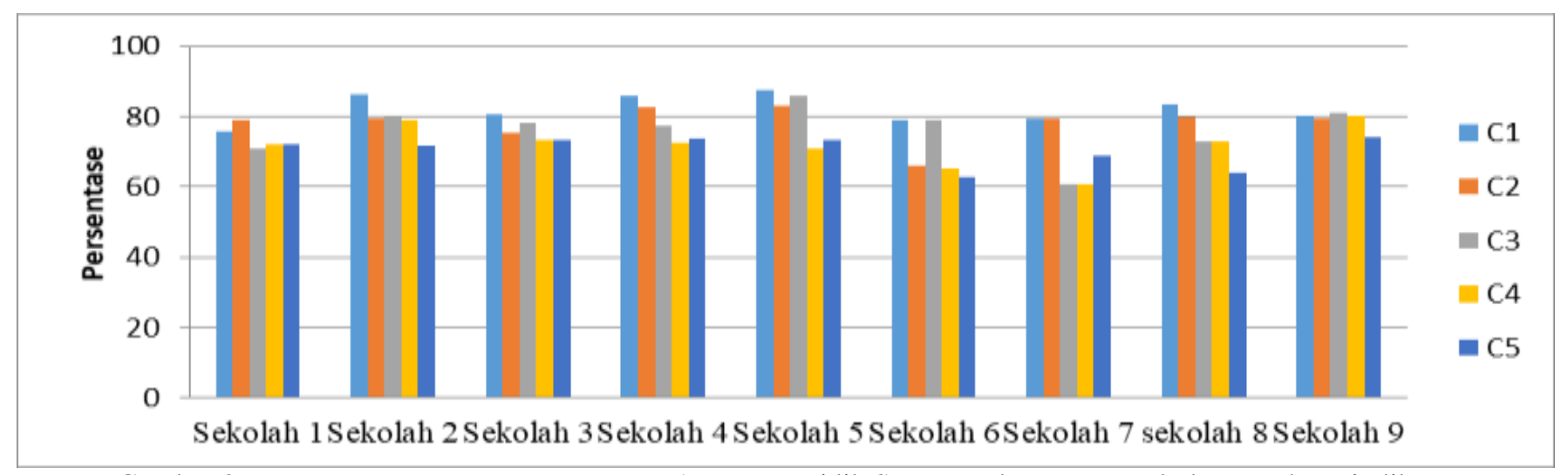

Gambar 2. Data Penguasaan Konsep Dasar IPA Peserta Didik SMPN Kabupaten Lombok Tengah Perindikator

Berdasarkan Gambar 2 menunjukkan bahwa nilai rata-rata penguasaan konsep dasar IPA peserta didik pada indikator pertama yaitu mengingatmemperoleh skor lebih tinggi dibandingkan indikator lainnya. Skor rata-rata keenam indikator penguasaan konsep peserta didik memperoleh skor $76,20 \%$ dengan kriteria tinggi. Indikator penguasaan konsep ang pertama yaitu mengingat memperoleh nilai tertinggi dibandingkan indikator lainnya (Yustiqvar et al, 2019 b; Wulandari et al, 2011).

Indikator keempat, kelima, dan keenam memperoleh nilai rata-rata lebih rendah dibandingkan indikator lainnya. Hal ini dipengaruhi oleh pertanyaanpertanyaan yang terdapat pada instrumen sudah menuju ke C4-C6 (menganalisis) dalam taksonomi Bloom. Pertanyaan-pertanyaan ini dianggap sulit oleh peserta didik, karena sebelumnya mereka hanya diberikan soal seputar di C1 (mengingat), C2 (pemahaman) dan C3 (mengaplikasikan). Mereka tidak siap atau belum dilatih berpikir dalam tingkat kognitif yang lebih tinggi.

Keberhasilan peserta didik juga dipengaruhi oleh kelengkapan fasilitas belajar. Peserta didik memiliki kesempatan terbatas dalam belajar materi, karena buku pelajaran IPA untuk peserta didik kedua kelas tidak cukup. Manajemen waktu dalam tes ini juga memiliki beberapa efek dalam prestasi peserta didik.

Lingkungan sekitar juga merupakan salah satu faktor yang mempengaruhi keberhasilan proses belajar mengajar. Suatu penggunaan teknologi dalam pembelajaran jarang dilakukan, karena fasilitas terbatas; seperti akses internet lambat, meskipun pelaksanaan Kurikulum 2013 menekankan teknologi berbasis pembelajaran komunikatif. Alasan tersebut 
yang menyebabkan efek yang dihasilkan oleh pembelajaran tidak optimal.

Penguasaan konsep peserta didik terhadap suatu materi yang dipelajari mempengaruhi kemampuan berpikir kritis (Lestari et al, 2017). Hal yang perlu diingat adalah segala bentuk berpikir kritis tidak mungkin dapat dilakukan tanpa komponen utama yaitu pengetahuan. Pengetahuan adalah sesuatu yang digunakan untuk berpikir kritis dan juga diperoleh sebagai hasil berpikir kritis (Surya, 2015).

\section{Kesimpulan}

Berdasarkan hasil penelitian, disimpulkan bahwa kemampuan berpikir kritis peserta didik sembilan sekolah SMPN di Lombok Tengah sebesar $71,69 \%$ dengan kriteria tinggi. Indikator berpikir kritis kedua yaitu membuat penjelasan lebih lanjut, memperoleh skor tertinggi dibandingkan indikator yang lain. Penguasaan konsep dasar IPA peserta didik sebesar 76,20\% dengan kriteria tinggi. Indikator penguasaan konsep pertama yaitu mengingat, memperoleh skor lebih tinggi dibandingkan indikator lainnya.

\section{Daftar Pustaka}

Agip, Z. (2009). Penelitian Tindakan Kelas untuk Guru SD, SLB, dan TK.Yrama Widya Bandung.

Alfonso, D. V. (2015). Evidence of Critical Thinking in High School Humanities Classrooms (Evidencias del Pensamiento Crítico en las Clases de Ciencias Humanas en Bachillerato). GIST Education and Learning Research Journal, 11(2), 26-44.

Amijaya, L. S., Ramdani, A., \& Merta, I. W. (2018). Pengaruh Model Pembelajaran Inkuiri Terbimbing terhadap Hasil Belajar dan Kemampuan Berpikir Kritis Peserta Didik. Jurnal Pijar Mipa, 13(2), 94-99.

Arikunto, S. (2013). Prosedur Penelitian Suatu Praktek. Jakarta: Rineka Cipta

Bloom, B. S. (1956). Taxonomy of educational objectives. Vol. 1: Cognitive domain. New York: McKay, 20-24.

Ennis, R. H. (2018). Critical thinking across the curriculum: A vision. Topoi, 37(1), 165-184.

Hadisaputra, S., Gunawan, G. \& Yustiqvar, M. (2019). Effects of Green Chemistry Based Interactive Multimedia on the Students' LearningOutcomesand Scientific Literacy. Journal of Advanced Research in Dynamical and Control Systems, 11(7), 664-674
Hasanah, J., Jamaludin, J., \& Prayitno, G. H. (2019). Bahan Ajar IPA Berbasis Inkuiri Terstruktur Untuk Meningkatkan Literasi Sains Peserta Didik SMP. Jurnal Pijar Mipa, 14(2), 18-24.

Hughes, C. (2014). Theory of Knowledge aims, objectives and assessment criteria: An analysis of critical thinking descriptors. Journal of Research in International Education, 13(1), 3045.

Ihsan, M. S., Ramdani, A., \& Hadisaputra, S. (2019). Pengembangan E-Learning Pada Pembelajaran Kimia Untuk Meningkatkan Kemampuan Berpikir Kritis Peserta Didik. Jurnal Pijar Mipa, 14(2), 84-87

Jufri, A.W (2013). Belajar dan Pembelajaran Sains. Bandung: Pustaka Rineka Cipta.

Karim, A. (2015). Pengaruh Gaya Belajar dan Sikap Siswa Pada Pelajaran Matematika Terhadap Kemampuan Berpikir Kritis Matematika. Formatif: Jurnal Ilmiah Pendidikan MIPA, 4(3), 188-195

Lestari, P. A. S., Gunawan, G., \& Kosim, K. (2019). Model Pembelajaran Discovery Dengan Pendekatan Konflik Kognitif Berorientasi Pada Kemampuan Berpikir Kritis Peserta Didik. Jurnal Pendidikan Fisika dan Teknologi, 5(1), 118-123.

Lestari, S., Mursali, S., \& Royani, I. (2019). Pengaruh Model Pembelajaran Langsung Berbasis Praktikum Terhadap Keterampilan Proses Sains Dan Kemampuan Berpikir Kritis Siswa. Bioscientist: Jurnal Ilmiah Biologi, 6(1), 54-62.

Permatasari, I., Ramdani, A., \& Syukur, A. (2019). Pengembangan Bahan Ajar IPA Berbasis Inkuiri Terintegrasi Sets (Science, Environment, Technology And Society) pada Materi Sistem Reproduksi Manusia. Jurnal Pijar Mipa, 14(2), 74-78.

Puspitasari, A. D. (2015). Efektifitas Pembelajaran Berbasis Guided Inquiry untuk Meningkatkan Literasi Sains Siswa. Omega: Jurnal Fisika dan Pendidikan Fisika, 1(2), 1-5.

Putra, P. D. A. (2015). Pengembangan Sistem ELearning untuk Meningkatkan Keterampilan Berpikir Kritis Mahasiswa Pendidikan Fisika. Jurnal Fisika Indonesia, 19(55), 45-49

Qurniati, D., Andayani, Y. \& Muntari. (2015). Peningkatan Keterampilan Berpikir Kritis Melalui Model Pembelajaran Discovery Learning. Journal Penelitian Pendidikan IPA, 1(5), 58-69 
Ramdani, A. (2018). Efektivitas Pengunaan Media Belajar untuk Penumbuhan Literasi Sains Tema Kesehatan Lingkungan. Jurnal Akrab, 6(1), 1929

Simbolon, E. R., \& Tapilouw, F.S. (2015). Pengaruh Pembelajaran Berbasis Masalah dan Pembelajaran Kontekstual Terhadap Berpikir Kritis Peserta didik SMP. Jurnal Edusains. 7(1), 97-104

Singh, H. R. \& Rahman, S. A. 2012. An Approach for Environmental Education by Non-Governmental Organizations (NGOs) in Biodiversity Conservation. Procedia - Social and Behavioral Sciences 42(2012) pp.144-152.

Sulistyowarni, P. A. D., Prahani, B. K., Supardi, Z. A. I., \& Jatmiko, B. (2019, February). The effectiveness of OR-IPA teaching model to improve students' critical thinking skills on senior high school physics subject. In Journal of Physics: Conference Series (Vol. 1157, No. 3, p. 032011). IOP Publishing.

Sulistyowati, N., Widodo, A. T. W. T., \& Sumarni, W. (2012). Efektivitas model pembelajaran guided discovery learning terhadap kemampuan pemecahan masalah kimia. Chemistry in education, 1(2). 48-55

Surya, M. (2015). Strategi Kognitif dalam Proses Pembelajaran. Bandung: Alfabeta.

Suryani, A. I., Jufri, A. W., \& Setiadi, D. (2017). Pengaruh Model Pembelajaran 5E Terintegrasi Pendekatan Saintifik Terhadap Kemampuan Literasi Sains Siswa Smpn 1 Kuripan Tahun Ajaran 2016/2017. Jurnal Pijar Mipa, 12(1), 3943

Wulandari, M. W., Liliasari, M., \& Supriyanti, M. T. (2011). Problem Based Learning untuk
Meningkatkan Keterampilan Berpikir Kreatif dan Penguasaan Konsep Siswa pada Materi Larutan Penyangga. Jurnal Pengajaran MIPA, 16(2), 116-121.

Yustiqvar, M., Gunawan, G., \& Hadisaputra, S. (2019 a). Green Chemistry Based Interactive Multimedia on Acid-Base Concept. In Journal of Physics: Conference Series (Vol. 1364, No. 1, p. 012006). IOP Publishing.

Yustiqvar, M., Hadisaputra, S., \& Gunawan, G. (2019 b). Analisis Penguasaan Konsep Siswa yang Belajar Kimia Menggunakan Multimedia Interaktif Berbasis Green Chemistry. Jurnal Pijar Mipa, 14(3), 135-140.

Zaini, M. (2016). Guided inquiry based learning on the concept of ecosystem toward learning outcomes and critical thinking skills of high school students. IOSR Journal of Research \& Method in Education (IOSR-JRME), 6(6), 50-55.

Zakrah, Z., Nur L., \& Kusmivati. 2015. Pengaruh Strategi Pembelajaran Discovery terhadap Kemampuan Berpikir Kritis Peserta Didik Pada Mata Pelajaran IPA Kelas VIII di SMPN 3 Gunungsari Tahun Ajaran 2014/2015. Jurnal Pijar MIPA, 10(1), 57-63.

Zulkarnain, Z., Andayani, Y., \& Hadisaputra, S. (2019). Peningkatan Keterampilan Berpikir Kritis Peserta Didik Pada Pembelajaran Kimia Menggunakan Model Pembelajaran Preparing Dong Concluding. Jurnal Pijar Mipa, 14(2), 96100. 